\title{
Shrinkage Analysis on Thick Plate Part using Response Surface Methodology (RSM)
}

\author{
M. Isafiq ${ }^{1}, Z$. Shayfull ${ }^{1,2, *}$, S.M. Nasir ${ }^{1,2,3}, M . M$. Rashidi $^{4}, M$. Fathullah $^{1,2}$ and N.Z. \\ Noriman $^{5}$ \\ ${ }^{1}$ School of Manufacturing Engineering, Universiti Malaysia Perlis, Kampus Tetap Pauh Putra, 02600 \\ Arau, Perlis, Malaysia \\ ${ }^{2}$ Green Design and Manufacture Research Group, Center of Excellence Geopolymer and Green \\ Technology (CEGeoGTech), Universiti Malaysia Perlis, 01000 Kangar, Perlis, Malaysia. \\ ${ }^{3}$ Centre For Diploma Studies, Universiti Malaysia Perlis, Malaysia. \\ ${ }^{4}$ Faculty of Mechanical Engineering, Universiti Malaysia Pahang, 26600 Pekan, Pahang, Malaysia. \\ ${ }^{5}$ Center of Excellence Geopolymer and Green Technology (CEGeoGTech), Faculty of Engineering \\ Technology (FETech), Universiti Malaysia Perlis (UniMAP), Level 1 Block S2, UniCITI Alam.
}

\begin{abstract}
The work reported herein is about an analysis on the quality (shrinkage) on a thick plate part using Response Surface Methodology (RSM). Previous researches showed that the most influential factor affecting the shrinkage on moulded parts are mould and melt temperature. Autodesk Moldflow Insight software was used for the analysis, while specifications of Nessei NEX 1000 injection moulding machine and P20 mould material were incorporated in this study on top of Acrylonitrile Butadiene Styrene (ABS) as a moulded thermoplastic material. Mould temperature, melt temperature, packing pressure and packing time were selected as variable parameters. The results show that the shrinkage have improved $42.48 \%$ and $14.41 \%$ in parallel and normal directions respectively after the optimisation process.
\end{abstract}

\section{Introduction}

Injection moulding is a very tough and complex process. This process is related to many fields of engineering such as fluid dynamics, static and dynamic, heat transfer, friction, material polymer and theory of control [1].

The term injection moulding is an oversimplified description of a quite complicated process that is controllable within specified limits. Melted or plasticized plastic material is injected by force into a mould cavity. The process is one of the most economical methods for mass production from simple to complex products. The machine parameters in injection moulding are among important factors that need to be considered to ensure the moulded part is produced in good quality.

Shrinkage is a very common defect in the injection moulding process. The value of shrinkage needs to be minimised to the lowest possible value to obtain better quality of moulded parts produced. Shrinkage occurs due to the relaxation of the polymer chain

\footnotetext{
*Corresponding author: shayfull@unimap.edu.my
} 
molecules during the molten plastic cools down in the mould. A large value of mould temperature will make a large volume of shrinkage to the part due to the increase of the molecular energy. To overcome this issue, therefore some machine parameters need to be considered.

Previous researches highlighted on some machine parameters such as mould temperature $\left({ }^{\circ} \mathrm{C}\right)$, melt temperature $\left({ }^{\circ} \mathrm{C}\right)$, cooling time $(\mathrm{s})$ and packing pressure $(\mathrm{MPa})$ to overcome the shrinkage defect thus producing a better quality of the moulded parts.

Chen et al. [4] proposed a mathematical model to reduce the value of shrinkage variation of the thin surface moulding part using RSM. A thin shell part was used as a case study. The specimen was moulded using material from Acrylonitrile butadiene styrene (ABS). Four parameters such as melt temperature, injection pressure, packing pressure and packing time were selected as a variable parameter. From the results, shrinkage had reduced $0.981 \%$ after optimization.

Mostafa et al. [5] attempted to minimise the volume of shrinkage and warpage on a moulded fuel filter using polyamide. Mould temperature, melt temperature and injection pressure were considered as variable parameters. The response surface model was interfaced with an effective Genetic Algorithm (GA) to determine an optimum value of process parameters. The results of ANOVA and confirmation experiments showed that the quadratic models of the shrinkage and warpage were fairly well fitted with the experimental values. The values of shrinkage presented the reduction of $26.8 \%$ after optimisation.

Similarly, in different paper, Kurtaran and Erzurumlu [6] reported about their investigation of the efficiency of integrating finite element analysis, statistical design of experiment method, response surface methodology, and GA to minimise warpage on lamp base from the ceiling of bus moulded using acrylonitrile butadiene styrene (ABS). Analysis of variance (ANOVA) was used to find the significance parameters on the warpage. Mould temperature $\left({ }^{\circ} \mathrm{C}\right)$, packing time $(\mathrm{s})$, packing pressure $(\mathrm{MPa})$ and cooling time $(\mathrm{s})$ are selected as variable parameters. As a result, the values of warpage reduced $37.8 \%$ after optimisation.

In this paper, the effects of the process conditions on the shrinkage of injection moulded parts produced using ABS material were determined by the RSM method based on the input of variable parameters of the injection moulding process such as coolant inlet temperature $\left({ }^{\circ} \mathrm{C}\right)$, melt temperature $\left({ }^{\circ} \mathrm{C}\right)$, packing pressure $(\mathrm{MPa})$ and cooling time $(\mathrm{s})$. In order to minimise such defect in plastic injection moulding, Design of Experiment (DOE) with full factorial design and RSM were applied. The significant factors that contribute to the shrinkage defect were identified from DOE analysis. Furthermore, an optimal set of process conditions can be predicted from a polynomial regression equation that had been modelled from list of experiments [7]. Thick plate part was selected as a case study and Autodesk Moldflow Insight (AMI) 2012 was used to simulate and identify the shrinkage on the moulded parts.

\section{Methodology}

\subsection{Simulation}

The thick plate part as shown in Figure 1 moulded using Acrylonitrile Butadiene Styrene (ABS) was used as a case study. Thickness of the part is $4 \mathrm{~mm}$ and diameter of cooling channel is $8 \mathrm{~mm}$. The $3 \mathrm{D}$ meshed model with the thickness of $2.5 \mathrm{~mm}$ was applied on the moulded parts using Autodesk Moldflow Insight (AMI) 2012. 3D modelling of the part and feed system was exported into AMI as well as construct the appropriate diameter, position, and cooling channels layout. The simulation starts with the fill analysis and the ram 
position was determined accordingly. The inputs in this stage was melt temperature $\left({ }^{\circ} \mathrm{C}\right)$ and mould temperature $\left({ }^{\circ} \mathrm{C}\right)$, while the output was set as fill time (s) and shear rate $\left(\mathrm{s}^{-1}\right)$ before performing the Fill + Pack analysis. From the analysis, an appropriate fill time, packing time and packing pressure were determined. The input in this stage was mould temperature $\left({ }^{\circ} \mathrm{C}\right)$, melt temperature $\left({ }^{\circ} \mathrm{C}\right)$ and ram position $(\mathrm{mm})$. The next stage was cool (FEM) analysis to obtain an appropriate cooling time (s).

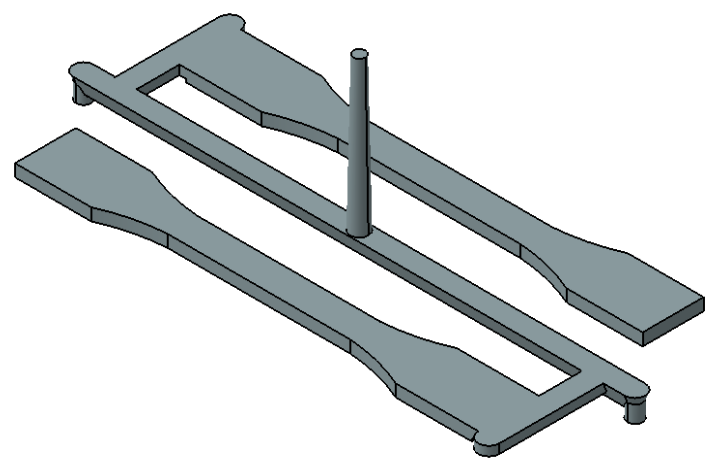

Fig. 13. Thick plate part with a gating system

\subsection{Mould and thermoplastic material.}

Mould Steel P20 was selected as a mould insert in this study. The mould insert was meshed using 3D mesh to simulate in Cool (FEM) analysis using AMI software. ABS material Polylac PA-777B manufactured by Chi Mei Corporation was used as a thermoplastic material to mould the part. The properties of thermoplastic and mould insert material are shown in Table 1 and 2 respectively.

Table 8. Physical and mechanical properties of ABS material.

\begin{tabular}{|l|l|}
\hline Properties & Value \\
\hline Specific heat, $\mathrm{C}_{\mathrm{p}}\left(\mathrm{J} / \mathrm{kg}^{\circ} \mathrm{C}\right)$ & 1464.7 \\
\hline Elastic modulus, $\mathrm{E}(\mathrm{MPa})$ & $2.24 \times 10^{3}$ \\
\hline Poisson's ratio, $v$ & 0.392 \\
\hline Thermal conductivity, $K\left(\mathrm{w} / \mathrm{m}^{\circ} \mathrm{C}\right)$ & 0.178 \\
\hline Melt density, $\left(\mathrm{g} / \mathrm{cm}^{3}\right)$ & 0.96 \\
\hline
\end{tabular}

Table 9. Properties of P20 mould steel

\begin{tabular}{|l|l|}
\hline Properties & Value \\
\hline Mould density, $\left(\mathrm{g} / \mathrm{cm}^{3}\right)$ & 7.8 \\
\hline Mould specific heat $(\mathrm{J} / \mathrm{kgs})$ & 460 \\
\hline Thermal conductivity, $K\left(\mathrm{w} / \mathrm{m}^{\circ} \mathrm{C}\right)$ & 29 \\
\hline Elastic modulus, $E(\mathrm{MPa})$ & $2.0 \times 10^{5}$ \\
\hline Poisson's ratio, $v$ & 0.33 \\
\hline Mould coefficient of thermal expansion $(1 / \mathrm{C})$ & $1.2 \times 10^{-5}$ \\
\hline
\end{tabular}




\subsection{Injection moulding machine}

In the simulation, the specification of injection moulding machine Nessei NEX1000 has been set in the AMI software. The specification of the injection moulding machine used is shown in Table 3.

Table 3. Injection moulding machine specification.

\begin{tabular}{|l|c|}
\hline Description & Value \\
\hline Maximum machine injection stroke, $(\mathrm{mm})$ & 75 \\
\hline Maximum machine injection rate $\left(\mathrm{cm}^{3} / \mathrm{s}\right)$ & 185 \\
\hline Machine screw diameter $(\mathrm{mm})$ & 28 \\
\hline Machine pressure limit $(\mathrm{MPa})$ & 243 \\
\hline Maximum machine clamp force (tonne) & 80 \\
\hline
\end{tabular}

\subsection{Design of Experiment (DOE)}

Two level full factorial design with four factors was selected as an experimental design to estimate the main effects and interactions on the shrinkage of the moulded part using Design Expert 7.0 software. The factorial design was conducted to observe the curvature in RSM where the second order model was proposed if the curvature is significant. Mould temperature $\left({ }^{\circ} \mathrm{C}\right)$, melt temperature $\left({ }^{\circ} \mathrm{C}\right)$, packing pressure $(\mathrm{MPa})$ and packing time $(\mathrm{s})$ are four independent factors that are considered in this study. Levels for each factor are illustrated in Table 4.

Table 4. Factors and levels for DOE.

\begin{tabular}{|c|c|c|}
\hline \multirow{2}{*}{ Factors } & \multicolumn{2}{|c|}{ Level } \\
\cline { 2 - 3 } & Minimum & Maximum \\
\hline Mould temperature, $\mathrm{A}\left({ }^{\circ} \mathrm{C}\right)$ & 40 & 90 \\
\hline Melt temperature, $\mathrm{B}\left({ }^{\circ} \mathrm{C}\right)$ & 220 & 270 \\
\hline Packing pressure, $\mathrm{C}(\mathrm{MPa})$ & 30 & 70 \\
\hline Cooling time, $\mathrm{D}(\mathrm{s})$ & 8 & 12 \\
\hline
\end{tabular}

\subsection{Response Surface Methodology (RSM)}

RSM method is widely used as a tool for modelling the prediction and optimisation in various areas [7-9]. It is an empirical model to define the relationship between the various processing of variable parameters and responses according to desire criteria and searches for the significance of these process parameters in the coupled responses [10].

As much as 30 runs of experiments involved in this study were generated using the specified conditions, according to the rotatable Central Composite Design (CCD) design to minimise the shrinkage on the thick plate part. In the determination of the shrinkage on the moulded parts, the lowers of shrinkage are the better the indication of the response characteristics. Therefore, the desired responses are seen as the smaller-the-better characteristic and influence each other relatively [11]. 


\subsection{Shrinkage measurement.}

Shrinkage on the thick plate part can be calculated according to the Eq.1 in parallel to the melt flow direction, $S_{p}$ and Eq. 2 for normal to the melt flow direction, $S_{n}$. The average of shrinkage was measured for both of cavities.

$$
\begin{gathered}
S_{p}=100 \frac{l_{c}-l_{1}}{l_{c}} \\
S_{n}=100 \frac{b_{c}-b_{1}}{b_{c}}
\end{gathered}
$$

where, $l_{c}$ is distance before deformation $(\mathrm{mm})$ and $l_{1}$ is distance after deformation $(\mathrm{mm})$. $b_{c}$ is distance before deformation $(\mathrm{mm})$ and $b_{1}$ is distance after deformation $(\mathrm{mm})$. The average value of shrinkage was calculated from shrinkage in normal and parallel directions to the melt flow for both of cavities.

\section{Results and Discussion}

The simulation conducted using DOE indicated that melt temperature is the main factor contributing to the shrinkage defect. This result is in line with Altan [12] who found that the packing pressure is the most significant factor for shrinkage and followed by melt temperature. Besides, Azaman et al. [13] also reported that packing pressure has a significant effect on shrinkage where the higher packing pressure resulted a lower shrinkage and vice versa. This trend also agreed by Mehat et al. [14] who indicated that shrinkage significantly reduced by increasing the packing pressure. On the other hand, the cooling time was agreed by Azaman et al. [13] to have less effect on the shrinkage on the moulded parts.

The regression model from Table 5 shows the relationship between the shrinkage and all input parameters which are mould temperature (A), melt temperature (B), packing pressure (C) and packing time (D) was established by Design Expert software and represented as Eq. 3 for shrinkage for parallel and Eq. 4 for shrinkage for normal,

$$
\begin{gathered}
S_{p}=0.42568+\left(6.11594 \times 10^{-3} \times B\right)+(0.040482 C)-(0.23397 D) \\
-\left(2.2562510 \times 10^{-4} \times B C\right)+\left(7.325 \times 10^{-4} \times B D\right) \\
+\left(8.15625 \times 10^{-4} \times C D\right) \\
S_{n}=14.58-(2.01 * A)-(0.079 * B)+ \\
(2.89 * c)+(0.15 * D)
\end{gathered}
$$

where $\mathrm{A}$ is mould temperature $\left({ }^{\circ} \mathrm{C}\right), \mathrm{B}$ melt temperature $\left({ }^{\circ} \mathrm{C}\right), \mathrm{C}$ packing pressure (MPa) and $\mathrm{D}$ is packing time (s).

The probability of P-value obtained from ANOVA is less than 0.05 indicating that the model is very significant for both types of shrinkage as shown in Tables 6 and 7. Among the four independent variables, the effect of packing time is the least significant on the shrinkage. Eq. 3 and Eq. 4 was applied to calculate the values of the shrinkage. 
Table 5. Parameter setting in DOE

\begin{tabular}{|c|c|c|c|c|c|c|}
\hline \multirow[b]{2}{*}{ Run } & \multicolumn{4}{|c|}{$\begin{array}{l}\text { Setting parameters for injection } \\
\text { moulding simulation }\end{array}$} & \multicolumn{2}{|c|}{$\begin{array}{c}\text { Average simulation value } \\
\text { of shrinkage }(\%)\end{array}$} \\
\hline & 를 & 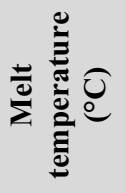 & 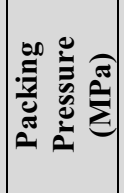 & 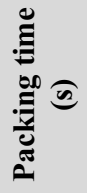 & 气 & हूँ \\
\hline 1 & 90 & 270 & 30 & 17.3 & 1.365 & 0.090 \\
\hline 2 & 40 & 270 & 70 & 7.3 & 0.830 & 0.050 \\
\hline 3 & 65 & 245 & 50 & 12.3 & 1.120 & 0.070 \\
\hline 4 & 65 & 245 & 50 & 12.3 & 1.120 & 0.070 \\
\hline 5 & 90 & 270 & 70 & 17.3 & 1.020 & 0.060 \\
\hline 6 & 40 & 220 & 30 & 17.3 & 0.7350 & 0.045 \\
\hline 7 & 90 & 270 & 30 & 7.3 & 1.370 & 0.090 \\
\hline 8 & 90 & 220 & 70 & 7.3 & 1.080 & 0.070 \\
\hline 9 & 40 & 270 & 70 & 17.3 & 0.850 & 0.050 \\
\hline 10 & 65 & 245 & 50 & 12.3 & 1.120 & 0.070 \\
\hline 11 & 90 & 270 & 70 & 7.3 & 0.970 & 0.060 \\
\hline 12 & 40 & 220 & 70 & 17.3 & 0.850 & 0.050 \\
\hline 13 & 90 & 220 & 70 & 17.3 & 0.970 & 0.060 \\
\hline 14 & 40 & 220 & 30 & 7.3 & 1.1650 & 0.0750 \\
\hline 15 & 90 & 220 & 30 & 7.3 & 1.255 & 0.080 \\
\hline 16 & 90 & 220 & 30 & 17.3 & 0.370 & 0.685 \\
\hline 17 & 40 & 220 & 70 & 7.3 & 0.845 & 0.055 \\
\hline 18 & 40 & 270 & 30 & 17.3 & 1.250 & 0.085 \\
\hline 19 & 40 & 270 & 30 & 7.3 & 1.270 & 0.090 \\
\hline 20 & 65 & 245 & 50 & 12.3 & 1.015 & 0.070 \\
\hline 21 & 65 & 245 & 30 & 12.3 & 1.160 & 0.080 \\
\hline 22 & 65 & 270 & 50 & 12.3 & 1.010 & 0.070 \\
\hline 23 & 65 & 245 & 50 & 17.3 & 1.115 & 0.070 \\
\hline 24 & 65 & 245 & 50 & 12.3 & 1.015 & 0.070 \\
\hline 25 & 65 & 245 & 50 & 7.3 & 0.975 & 0.070 \\
\hline 26 & 65 & 220 & 50 & 12.3 & 0.935 & 0.0650 \\
\hline 27 & 65 & 245 & 70 & 12.3 & 0.810 & 0.060 \\
\hline 28 & 90 & 245 & 50 & 12.3 & 0.965 & 0.070 \\
\hline 29 & 40 & 245 & 50 & 12.3 & 1.025 & 0.070 \\
\hline 30 & 65 & 245 & 50 & 12.3 & 1.015 & 0.070 \\
\hline
\end{tabular}


Table 6. ANOVA of response surface model for parallel.

\begin{tabular}{|c|c|c|c|c|c|c|}
\hline Source & $\begin{array}{c}\text { Sum of } \\
\text { Squares }\end{array}$ & df & $\begin{array}{c}\text { Mean } \\
\text { Square }\end{array}$ & F Value & $\begin{array}{l}\text { p-value P model } \\
>F\end{array}$ & \\
\hline Model & 0.86 & 6 & 0.14 & 9.77 & $<0.0001$ & 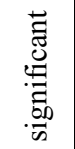 \\
\hline B-Melt temp & 0.17 & 1 & 0.17 & 11.36 & 0.0028 & \\
\hline C-Packing pressure & 0.16 & 1 & 0.16 & 11.16 & 0.0030 & \\
\hline D- packing time & 0.08 & 1 & 0.08 & 5.79 & 0.0250 & \\
\hline $\mathrm{BC}$ & 0.20 & 1 & 0.20 & 13.91 & 0.0012 & \\
\hline $\mathrm{BD}$ & 0.13 & 1 & 0.13 & 9.16 & 0.0062 & \\
\hline $\mathrm{CD}$ & 0.11 & 1 & 0.11 & 7.27 & 0.0132 & \\
\hline Residual & 0.32 & 22 & 0.01 & & & \\
\hline Lack of fit & 0.31 & 18 & 0.01 & 8.43 & 0.0259 & 它. \\
\hline Pure error & $\begin{array}{r}8.26 \\
\times 10^{-3} \\
\end{array}$ & 4 & $\begin{array}{c}2.06 \\
\times 10^{-3} \\
\end{array}$ & & & \\
\hline Cor total & 1.19 & 29 & & & & \\
\hline
\end{tabular}

Table 7. ANOVA of the response surface model for normal.

\begin{tabular}{|c|c|c|c|c|c|c|}
\hline Source & $\begin{array}{c}\text { Sum of } \\
\text { Squares }\end{array}$ & df & $\begin{array}{l}\text { Mean } \\
\text { Square }\end{array}$ & F Value & $\begin{array}{l}\text { p-value } P \\
\text { model }>F\end{array}$ & \\
\hline Model & 223.43 & 4 & 55.86 & 7.40 & 0.0005 & 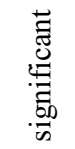 \\
\hline A-Mould temp & 72.58 & 1 & 72.58 & 9.62 & 0.0049 & \\
\hline B-melt temp & 0.096 & 1 & 0.09 & 0.013 & 0.1090 & \\
\hline C-packing pressure & 150.34 & 1 & 150.34 & 19.93 & 0.0002 & \\
\hline D-packing time & 0.41 & 1 & 0.41 & 0.054 & 0.4186 & \\
\hline Residual & 181.05 & 24 & 7.54 & & & \\
\hline Lack of Fit & 181.05 & 20 & 9.05 & & & z․ㅠ. \\
\hline Pure Error & 0.00 & 4 & 0.00 & & & \\
\hline Cor Total & 404.92 & 29 & & & & \\
\hline
\end{tabular}




\section{Optimisation}

To minimise the shrinkage on moulded parts, the optimal parameters should be determined. Design Expert software has been used in this study to utilise the results from the RSM method to obtain the minimum value of shrinkage. The best results for shrinkage after optimisation is presented in Table 8 .

Table 8. The results of shrinkage after optimisation.

\begin{tabular}{|l|c|}
\hline Factors & Value \\
\hline Mould temperature, $\mathrm{A}\left({ }^{\circ} \mathrm{C}\right)$ & 90 \\
\hline Melt temperature, $\mathrm{B}\left({ }^{\circ} \mathrm{C}\right)$ & 270 \\
\hline Packing pressure, $\mathrm{C}(\mathrm{MPa})$ & 70 \\
\hline Packing time, D (s) & 7.31 \\
\hline Shrinkage, $(\%)$ & Parallel :0.66 \\
Normal :0.08
\end{tabular}

\section{Conclusions}

The results obtained from this study are helpful in improving the quality and productivity of moulded parts. RSM method is one of the optimisation method which can be used to obtain the best setting parameters to minimise the shrinkage on moulded part. The mould temperature, melt temperature, packing pressure and packing time have been considered as variable parameters in this paper. As a result, packing pressure is concluded to be the main factor that highly affects the shrinkage of the thick plate part. The shrinkage on the thick plate parts was reduced $42.48 \%$ and $14.41 \%$ in parallel and normal directions to the material flow respectively, after optimisation using RSM.

\section{References}

1. C.K. Kwong, G.F. Smithb, W.S. Lauc, J. Mater. Process. Technol., 63, 463 (1997)

2. H. Zhou, Computer modeling for injection molding simulation, optimization and control (Wiley, 2013)

3. D.V. Rosato, D.V. Rosato, M.V. Rosato, Plastic product material and process selection handbook, 85 (Elsevier, 2004)

4. C.C. Chen, P.L. Su, Y.C. Lin, Int. J. Adv. Manuf. Tech., 45, 1087 (2002)

5. T.C. Chang, Polym. Eng. Sci., 41, 5 (2001)

6. D.V. Rosato, D.V. Rosato, M.G. Rosato, Injection molding handbook (Springer, 2000)

7. N.N. Aimi, H. Anuar, M.R. Manshor, W.B.W. Nazri, S.M. Sapuan, Ind. Crops Prod., 54, 291 (2014)

8. G. Chi, S. Hu, Y. Yang, T. Chen, Chem. Eng. Res. Des., 90, 1235 (2012)

9. A.M. Zain, H. Haron, S. Sharif, Expert. Syst. App., 37, 4650 (2010)

10. D.C. Montgomery, Design and analysis of experiments (Wiley, 2001)

11. W.C. Chen, D. Kurniawan, G. L. Fu, Adv. Mater. Res., 4, 1220 (2012)

12. M. Altan, Mater. Design, 31, 599 (2010)

13. M.D. Azaman, S.M. Sapuan, S. Sulaiman, E.S. Zainudin, A. Khalina, Mater. Design, 52, 1018 (2013)

14. N.M. Mehat, S. Kamaruddin, A.R. Othman, Adv. Mat. Res., 5, 2135 (2012) 